\title{
Pelayanan dan fasilitas kesehatan, biaya persalinan, dan kebijakan di tempat bersalin mempengaruhi ibu dalam memilih tempat bersalin di Kelurahan Kemiri Muka, Kecamatan Beji, Depok
}

\author{
Nourmayansa Vidya Anggraini ${ }^{1}$, Efa Apriyanti ${ }^{2}$, Ayuda Nia Agustian $^{3}$, Maharaufa Fathmanda $^{4}$ \\ ${ }^{1}$ Universitas Pembangunan Nasional Veteran Jakarta \\ ${ }^{2}$ Universitas Indonesia \\ ${ }^{3}$ Akademi Keperawatan Fatmawati \\ ${ }^{4}$ STIKep PPNI Jawa Barat
}

Keywords :

Faktor, Ibu, Kemiri Muka, Pemilihan

Tempat Bersalin

\section{Kontak :}

Nourmayansa Vidya Anggraini

Email : nourmayansa@upnvj.ac.id

Universitas Pembangunan Nasional

Veteran Jakarta

DOI : https://doi.org/10.15294/

kemas.v14i3.1562

\section{(C)2020J-Healt}

ini adalah artikel dengan akses terbuka dibawah licenci CC BY-NC-4.0

https://creativecommons.org/licenses/by-nc/4.0/

\begin{abstract}
Abstrak
Salah satu indicator derajat kesehatan suatu Negara adalah angka kematian ibu dan bayi. 52.4\% ibu-ibu di Indonesia memiliki akses ke pelayanan maternal. Angka Kematian Ibu (AKI) di Indonesia tahun 2008 menurut Survei Demografi Kesehatan Indonesia adalah 307 per 100.000 kelahiran hidup, jauh dari target yang seharusnya yaitu 110 per 100.000 kelahiran hidup. Tujuan umum penelitian ini adalah untuk mengetahui faktor-faktor berhubungan dengan keputusan ibu memilih tempat bersalin, diantaranya adalah pelayanan kesehatan, fasilitas kesehatan, biaya persalinan, dan kebijakan di tempat bersalin. Sample penelitian adalah ibu-ibu yang berada di kelurahan Kemiri Muka Depok berjumlah 125 orang. Penelitian ini menggunakan kuesioner dan Return rate $=100 \%$. Penelitian ini menggunakan metode cross sectional dan analisa data univariat menggunakan distribusi frekuensi serta bivariat menggunakan chi-square. Hasil penelitian menunjukan adanya hubungan bermakna antara dan fasilitas kesehatan ( $\mathrm{p}$ Value $=0.033$; $=$ 0.05) dengan pilihan tempat bersalin.
\end{abstract}

\section{Abstract}

One indicator of a country's health status is the maternal and infant mortality rate. $52.4 \%$ of mothers in Indonesia have access to maternal services. Maternal Mortality Rate (MMR) in Indonesia in 2008 according to the Demographic Health Survey of Indonesia is 307 per 100,000 live births, its far from the supposed target of 110 per 100,000 live births. The general objective of this study was to determine the factors associated with mother's decision when choosing a birth place, including the choice of giving birth. The factors that affect mother's decision when choosing a birth place are characteristic of the respondents and distance delivery and home place. Research sample is mothers residing in RW 03 Kelurahan Kemiri Muka - Depok totaling 125 people. This study uses a questionnaire and return rate $=100 \%$. This study uses cross sectional data analysis using univariate and bivariate frequency distribution using the chisquare test. The results showed that there was a significant relationship between respondent's education ( $p$-value $=0.009 ;=0.05)$, the husband's income \& (pvalue = $0.046 ;=0.05)$, and health facilities ( $p$-value $=0.033 ;=0.05)$ with $a$ choice of place of birth. 


\section{PENDAHULUAN}

Komitmen dalam menurunkan angka kematian ibu merupakan salah satu dari delapan tujuan utama komitmen bersama di bidang kesehatan pada The Millenium Development Goals (MDGs) for Health. Salah satu indikator untuk mengetahui derajat kesehatan suatu negara adalah angka kematian ibu dan bayi (Bapenas, 2007). Angka Kematian Ibu (AKI) di Indonesia masih sangat tinggi. Tingginya angka kematian ibu tidak hanya terjadi di wilayah terpencil saja. Hal ini juga terjadi di Depok yang berbatasan langsung dengan Jakarta yang merupakan pusat kota di Indonesia. Siswono (2008) menyatakan bahwa pada tahun 2008 sebanyak 9 ibu meninggal dunia saat melahirkan dan $90 \%$ disebabkan adanya perdarahan saat proses persalinan.

Keberadaan rumah sakit besar dengan fasilitas memadai ternyata tidak menyurutkan keberadaan klinik bersalin dan tempat-tempat bersalin yang tidak terlalu besar dengan fasilitas minimal. Klinik ini tersebar di pusat kota hingga ke pelosok wilayah Depok. Namun, sebaliknya keberadaan non tenaga kesehatan sebagai penolong persalinan pun masih menjadi pilihan ibu untuk bersalin. Bila ada pihak yang mengatakan bahwa kendala keuangan menjadi hambatan sehingga banyak ibu yang memilih non tenaga kesehatan sebagai penolong persalinan, hal ini tidaklah beralasan.

Jumlah rumah sakit dengan fasilitas yang baik, ternyata tidak menghilangkan hal buruk dan kekecewaan bagi pasiennya. Hal ini pun terjadi bagi ibu-ibu yang selesai melakukan proses persalinannya dan mendapatkan pelayanan yang tidak maksimal dari rumah sakit tempatnya bersalin. Angka kematian ibu dan bayi merupakan salah satu indikator untuk mengetahui derajat kesehatan suatu negara. Ibu-ibu di Indonesia yang memiliki akses ke pelayanan kesehatan maternal hanya berkisar 52.4\%. Angka Kematian Ibu (AKI) di Indonesia tahun 2008 menurut Survei Demografi Kesehatan Indonesia adalah 307 per 100.000 kelahiran hidup, jauh dari target yang seharusnya yaitu 110 per 100.000 kelahiran hidup. Tingginya angka kematian ibu tidak hanya terjadi di wilayah terpencil saja. Hal ini juga terjadi di Depok yang berbatasan langsung dengan pusat kota Indonesia. Tercatat sebanyak $9 \mathrm{ibu}$ meninggal dunia saat melahirkan pada tahun 2008 .

Seorang ibu dapat mempertimbangkan beberapa hal terkait pemilihan tipe-tipe rumah bersalin, seperti pertimbangan ekonomis, jarak, ataupun fasilitas yang tersedia, baik fasilitas fisik ataupun pelayanan yang terdapat di masing-masing tempat sakit bersalin tersebut. Pemilihan tempat bersalin memberikan pengaruh terhadap keberhasilan proses persalinan serta perawatan yang diterima ibu baik selama persalinan hingga kelahiran bayi. Pemilihan tempat bersalin dipengaruhi oleh berbagai faktor baik dari internal maupun eksternal ibu.

Permasalahan di atas yang melatarbelakangi penelitian ini, sehingga peneliti menganggap penting untuk mengetahui faktor yang menjadi pertimbangan ibu dalam memilih tempat bersalin dan melihat hubungan antara faktor-faktor yang melatarbelakangi ibu dalam memilih tempat bersalin dengan pilihan tempat bersalin.

\section{METODE}

Penelitian ini menggunakan desain korelasional. Teknik pemilihan tempat penelitian adalah didasarkan pada sebaran penduduk yang bervariasi (jenis pekerjaan, sosial ekonomi, dan lainnya) di kelurahan Kemiri Muka, Depok. Kelurahan Kemiri Muka terdiri dari 20 Rukun Warga (RW) dan 85 Rukun Tetangga (RT) dengan jumlah penduduk 29.872 Jiwa di tahun 2008 (data kantor kelurahan Kemiri Muka). Populasi target dalam penelitian adalah seluruh ibu-ibu muda berusia 20-35 tahun yang pernah 
melahirkan dan tinggal di Kelurahan Kemiri Muka, Kecamatan Beji, Kota Depok - Jawa Barat. Populasi sampling dalam penelitian adalah seluruh ibu-ibu muda berusia 20-35 tahun yang pernah melahirkan dan tinggal di Kelurahan Kemiri Muka, Kecamatan Beji, Kota Depok - Jawa Barat sebanyak 185 ibu. Penelitian ini menggunakan metode cross sectional dan analisa data univariat menggunakan distribusi frekuensi serta bivariat menggunakan chi-square.

\section{HASIL}

Hasil penelitian menunjukkan bahwa sebagian besar responden menganggap penting akan pelayanan kesehatan di tempat bersalin yang berkualitas sebanyak 60 orang (48\%). Keterangan lebih lengkap dapat dilihat pada diagram 1 di bawah ini.

Diagram Pie 1 Faktor Pelayanan Kesehatan di Tempat Bersalin Kelurahan Kemiri Muka, Depok tahun $2010(n=125)$

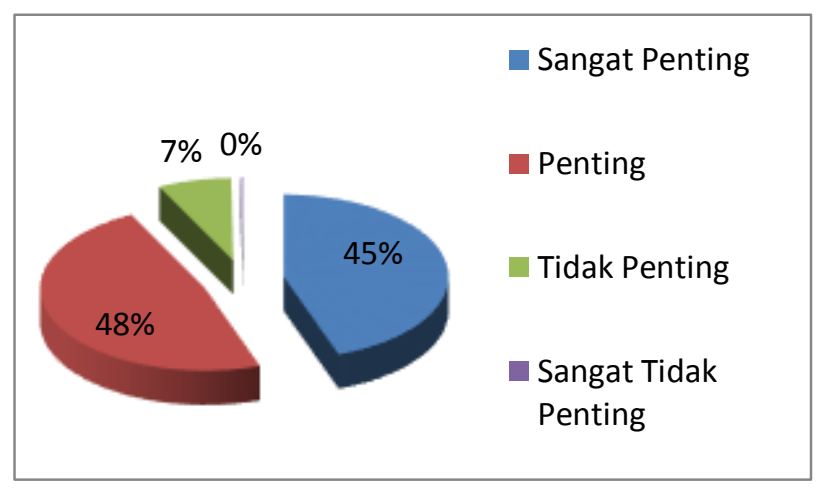

Hasil penelitian menunjukkan bahwa sebagian besar responden menganggap pentingnya fasilitas konsultasi setelah melahirkan, yaitu sebanyak $31 \%$. Keterangan lebih lengkap dapat dilihat pada diagram 2 di bawah ini.

Diagram Pie 2 Fasilitas Kesehatan di Tempat Bersalin yang Dibutuhkan Kelurahan Kemiri Muka, Depok tahun $2010(\mathrm{n}=125)$

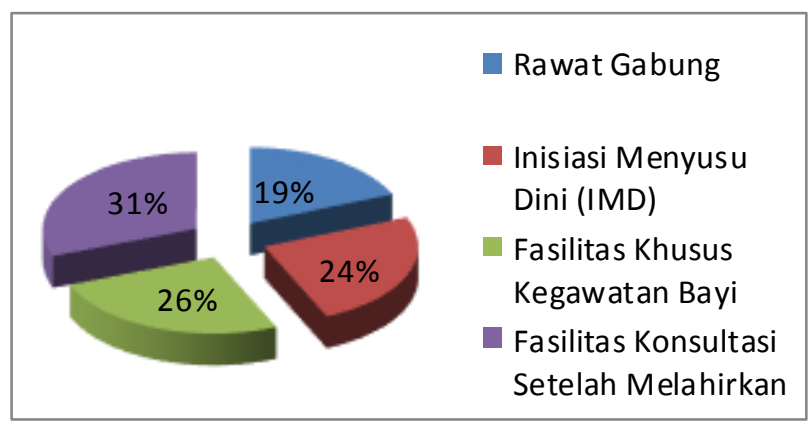

Hasil penelitian menghasilkan bahwa sebagian besar ibu berpendapat bahwa faktor biaya persalinan penting dalam pemilihan tempat bersalin yaitu 61 orang (55\%). Keterangan lebih lengkap dapat dilihat pada Diagram Pie 3 di bawah ini.

Diagram Pie 3 Faktor Biaya Persalinan Kelurahan Kemiri Muka, Depok tahun 2010 (n $=125$ )

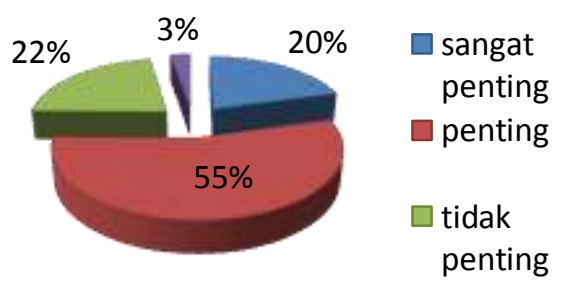

Hasil penelitian menunjukkan bahwa 70 orang $(56 \%)$ berpendapat bahwa kebijakan yang mendukung proses persalinan merupakan hal yang penting. Keterangan lebih lengkap dapat dilihat pada Diagram Pie 4 di bawah ini.

Diagram Pie 4 Faktor Kebijakan di Tempat Bersalin Kelurahan Kemiri Muka, Depok tahun $2010(\mathrm{n}=125)$

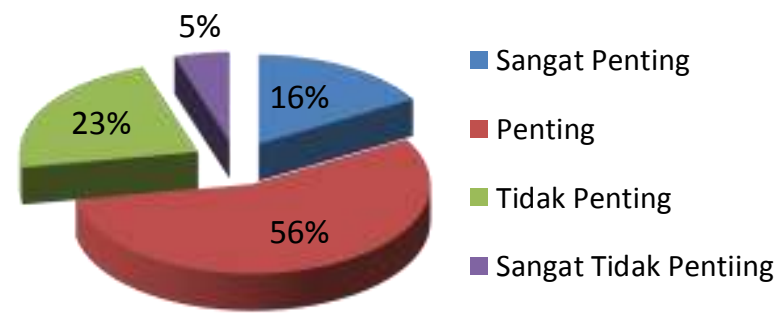

Hasil uji chi-square menunjukan bahwa tidak ada hubungan antara pelayanan kesehatan di 
tempat bersalin dengan pilihan tempat bersalin ( $p$ Value $=0.443 ; \alpha=0.05$ ). Lebih lengkap dapat dilihat pada tabel 1 dibawah ini.

Tabel 1 Hubungan Antara Pelayanan Kesehatan dengan Pilihan Tempat Bersalin Kelurahan Kemiri Muka, Depok tahun 2010 (n $=125$ )

\begin{tabular}{|c|c|c|c|c|c|}
\hline \multirow[t]{2}{*}{$\begin{array}{l}\text { Pelayanan } \\
\text { Kesehatan } \\
\end{array}$} & \multicolumn{2}{|c|}{$\begin{array}{c}\text { Jenis Rumah } \\
\text { Sakit }\end{array}$} & \multirow{2}{*}{ Total } & \multirow{2}{*}{$\mathbf{x}^{2}$} & \multirow[b]{2}{*}{$\begin{array}{c}\mathbf{P} \\
\text { Value }\end{array}$} \\
\hline & $\begin{array}{c}\text { Rumah } \\
\text { Sakit }\end{array}$ & $\begin{array}{c}\text { Non } \\
\text { Rumah } \\
\text { Sakit }\end{array}$ & & & \\
\hline Baik & 54 & 62 & 116 & & \\
\hline Buruk & 3 & 6 & 9 & 0.588 & 0.443 \\
\hline TOTAL & 57 & 68 & 125 & & \\
\hline
\end{tabular}

Hasil penelitian pada Ibu-ibu di Kelurahan Kemiri Muka dapat dikategorikan menjadi dua dalam memilih fasilitas kesehatan di tempat bersalin, yakni lengkap dan tidak lengkap. Responden yang memilih rumah sakit dengan fasilitas lengkap sebanyak 40 orang dan non rumah sakit dengan fasilitas lengkap sebanyak 35 orang. Sedangkan responden yang memilih rumah sakit dan non rumah sakit dengan fasilitas yang tidak lengkap masing-masing sebanyak 17 orang dan 33 orang. Hasil uji chi-square menunjukan bahwa ada hubungan antara fasilitas tempat bersalin dengan pilihan tempat bersalin ( $p$ Value $=0.033 ; \alpha=0.05$ ). Lebih lengkap dapat dilihat pada tabel 2 dibawah ini.

Tabel 2 Hubungan Antara Fasilitas Kesehatan dengan Pilihan Tempat Bersalin

Kelurahan Kemiri Muka, Depok tahun 2010

$$
(\mathrm{n}=125)
$$

\begin{tabular}{|c|c|c|c|c|c|}
\hline \multirow[t]{2}{*}{ Kesehatan } & \multicolumn{2}{|c|}{ Sakit } & \multirow{2}{*}{$\begin{array}{l}\text { Tot } \\
\text { al }\end{array}$} & \multirow[t]{2}{*}{$\mathrm{x}^{2}$} & \multirow{2}{*}{$\begin{array}{c}\mathbf{P} \\
\text { Value }\end{array}$} \\
\hline & $\begin{array}{c}\text { Rumah } \\
\text { Sakit }\end{array}$ & $\begin{array}{c}\text { Non } \\
\text { Rumah } \\
\text { Sakit }\end{array}$ & & & \\
\hline Lengkap & 40 & 35 & 75 & & \\
\hline $\begin{array}{l}\text { Tidak } \\
\text { Lengkap }\end{array}$ & 17 & 33 & 50 & 4.520 & 0.033 \\
\hline TOTAL & 57 & 68 & 125 & & \\
\hline
\end{tabular}

Hasil penelitian menunjukkan bahwa sebagian besar responden memiliki biaya terjangkau untuk jenis rumah sakit yaitu 64 orang. Hasil uji chi-square menunjukkan bahwa tidak ada hubungan antara biaya persalinan dengan pilihan tempat bersalin ( $\mathrm{p}$ value $=0.307 ; \alpha=0.05$ ). Lebih lengkap dapat dilihat pada tabel 3 dibawah ini.

Tabel 3 Hubungan Antara Biaya Persalinan dengan Pilihan Tempat Bersalin Kelurahan Kemiri Muka, Depok tahun $2010(n=125)$

\begin{tabular}{|c|c|c|c|c|c|}
\hline \multirow[t]{4}{*}{$\begin{array}{c}\text { Biaya } \\
\text { Persalinan }\end{array}$} & $\begin{array}{r}\text { Jenis } \\
\mathrm{S}\end{array}$ & Sakit & Total & $x^{2}$ & $\mathbf{P}$ \\
\hline & Rumah & Non & & & Value \\
\hline & Sakit & Rumah & & & \\
\hline & & Sakit & & & \\
\hline Terjangkau & 64 & 53 & 117 & & \\
\hline $\begin{array}{l}\text { Tidak } \\
\text { Terjangkau }\end{array}$ & 4 & 4 & 8 & 3.612 & 0.307 \\
\hline TOTAL & 68 & 57 & 125 & & \\
\hline
\end{tabular}

Hasil penelitian menunjukkan bahwa jumlah responden terbanyak memilih non rumah sakit dengan kebijakan yang mendukung proses persalinan sebagai tempat bersalin sebanyak 68 orang. Hasil uji chi-square menunjukkan bahwa tidak ada hubungan antara kebijakan di tempat bersalin dengan pilihan tempat bersalin ( $\mathrm{p}$ value $=0.119 ; \alpha=$ 0.05). Lebih lengkap dapat dilihat pada tabel 4 dibawah ini.

Tabel 4 Hubungan Antara Kebijakan di Tempat Bersalin dengan Pilihan Tempat Bersalin Kelurahan Kemiri Muka, Depok tahun $2010(n=125)$

\begin{tabular}{lc}
$\begin{array}{c}\text { Kebijakan } \\
\text { di Tempat }\end{array}$ & Jenis Rumah \\
\hline
\end{tabular}




\begin{tabular}{|c|c|c|c|c|c|}
\hline \multicolumn{3}{|l|}{ Bersalin } & \multirow[t]{2}{*}{ Total } & \multirow[t]{2}{*}{$\mathbf{x}^{2}$} & \multirow{2}{*}{$\begin{array}{c}\mathbf{P} \\
\text { Value }\end{array}$} \\
\hline & $\begin{array}{c}\text { Rumah } \\
\text { Sakit }\end{array}$ & $\begin{array}{c}\text { Non } \\
\text { Rumah } \\
\text { Sakit }\end{array}$ & & & \\
\hline Mendukung & 55 & 68 & 123 & & \\
\hline Tidak & 2 & 0 & 2 & 2.425 & 0.119 \\
\hline \multicolumn{6}{|l|}{ Mendukung } \\
\hline TOTAL & 57 & 68 & 125 & & \\
\hline
\end{tabular}

\section{PEMBAHASAN}

Hasil penelitian menunjukkan bahwa sebagian besar responden menganggap penting mendapatkan fasilitas kesehatan yang berkualitas di tempat bersalin, yakni sebanyak 64 orang $(51 \%)$ dan hanya sebanyak 1 orang (1\%) yang menganggap faktor fasilitas kesehatan di tempat bersalin sangat tidak penting dalam pemilihan tempat bersalin. Selain itu, sebagian besar respoden lebih memilih fasilitas konsultasi tambahan sebagai fasilitas kesehatan yang dipertimbangkan dalam pilihan tempat bersalin, yaitu sebanyak 39 orang $(31 \%)$.

Hasil penelitian menunjukkan bahwa ada hubungan bermakna antara fasilitas kesehatan di tempat bersalin dengan pilihan tempat bersalin. Hal ini menguatkan penelitian sebelumnya, yakni hasil penelitian Noerdin (2006) yang dilakukan di Lampung Utara (Lampung), Lebak (Banten), Indramayu (Jawa Barat), Solo (Jawa Tengah), Jembrana (Bali), Lombok Tengah (Nusa Tenggara Barat), dan Sumba Barat (Nusa Tenggara Timur), bahwa faktor fasilitas tempat bersalin berpengaruh terhadap pilihan tempat bersalin. Berdasarkan penelitian dapat diketahui bahwa fasilitas kesehatan di tempat bersalin memang menjadi faktor yang penting bagi seorang ibu dalam mengambil keputusan saat memilih tempat bersalin. Hal ini disebabkan ibu mempertimbangkan kelengkapan fasilitas rawat gabung, dukungan fasilitas inisiasi menyusu dini (IMD), kelengkapan fasilitas kegawatan bayi, seperti inkubator, ruang Neonatal Care Unit (NICU), dan yang paling banyak dipilih ibu adalah fasilitas konsultasi tambahan setelah bersalin.
Penelitian menunjukkan bahwa tidak ada hubungan bermakna antara biaya persalinan dengan pilihan tempat bersalin. Hal ini berbeda dengan penelitian Wibowo (1992) yang meneliti tentang faktor-faktor yang mempengaruhi tentang pemanfaatan pelayanan antenatal menemukan bahwa pendapatan keluarga per bulan berpengaruh terhadap pemanfaatan pelayanan kesehatan. Setiap institusi memiliki kebijakan yang mengatur setiap hal di dalamnya tidak terkecuali instansi kesehatan. Kebijakankebijakan yang dibuat untuk memberikan pelayanan yang optimal, namun tidak jarang kebijakan tersebut justru dianggap tidak sesuai dengan keinginan pengguna jasa. Kebijakan di tempat bersalin yang menjadi perhatian antara lain kebijakan terkait sistem rujukan dan perizinan mendokumentasikan proses persalinan. Hasil penelitian menunjukkan tidak ada hubungan bermakna antara kebijakan tempat bersalin dengan pemilihan tempat bersalin.

Berdasarkan penelitian ini dapat disimpulkan bahwa kebijakan yang mendukung proses persalinan tidak menjadi syarat mutlak bagi ibu untuk memilih tempat bersalin. Sebagian besar ibu memilih tempat bersalin yang memiliki sistem rujukan yang baik karena hal tersebut merupakan salah satu hal yang sangat esensial menyangkut keselamatan ibu dan bayi. Sedangkan untuk perizinan melakukan proses pendokumentasian proses persalinan dianggap tidak begitu penting. Hal ini dapat dipengaruhi oleh budaya ibu di mana merekam proses persalinan masih dianggap sebagai hal yang tabu dan ibu belum mengetahui kegunaan dari pendokumentasian proses persalinan tersebut.

Hasil penelitian menunjukkan tidak ada hubungan bermakna antara kualitas pelayanan kesehatan dengan pemilihan tempat bersalin. Hasil penelitian ini bertentangan dengan penelitian sebelumnya yang dilakukan oleh Surjadi (1997) berjudul "The Use of Health Services in A Slum Area of North Jakarta" bahwa salah satu faktor yang mempengaruhi keputusan untuk memilih suatu layanan adalah kualitas pelayanan kesehatan. Perbedaan kedua hasil penelitian tersebut 
dapat disebabkan oleh beberapa faktor, salah satunya adalah karakteristik sampel yang berbeda. Pada penelitian ini, sampel yang diambil adalah ibu yang tinggal di Kelurahan Kemiri Muka dengan dengan komposisi suku sebagian besar adalah Suku Jawa. Hal ini menyebabkan sistem kekerabatan antar tetangga sangat dekat sehingga tidak jarang dalam pengambilan keputusan lebih didasarkan pada rekomendasi dari tetangga ataupun orang yang dituakan di lingkungan mereka.

Hasil penelitian pada Ibu-ibu di Kelurahan Kemiri Muka dapat dikategorikan menjadi dua dalam memilih fasilitas kesehatan di tempat bersalin, yakni lengkap dan tidak lengkap. Responden yang memilih rumah sakit dengan fasilitas lengkap sebanyak 40 orang dan non rumah sakit dengan fasilitas lengkap sebanyak 35 orang. Sedangkan responden yang memilih rumah sakit dan non rumah sakit dengan fasilitas yang tidak lengkap masing-masing sebanyak 17 orang dan 33 orang. Hasil uji chi-square menunjukan bahwa ada hubungan antara fasilitas tempat bersalin dengan pilihan tempat bersalin ( $\mathrm{p}$ Value $=0.033 ; \alpha=0.05$ ) Seorang ibu dapat mempertimbangkan beberapa hal terkait pemilihan tipe-tipe rumah bersalin, seperti pertimbangan ekonomi, jarak, dan terutama fasilitas yang tersedia di tempat bersalin, baik fasilitas fisik ataupun pelayanan yang terdapat di masing-masing rumah sakit bersalin tersebut.

Hasil penelitian menunjukkan bahwa ada hubungan bermakna antara fasilitas kesehatan di tempat bersalin dengan pilihan tempat bersalin. Hal ini menguatkan penelitian sebelumnya, yakni hasil penelitian Noerdin (2006) yang dilakukan di Lampung Utara (Lampung), Lebak (Banten), Indramayu (Jawa Barat), Solo (Jawa Tengah), Jembrana (Bali), Lombok Tengah (Nusa Tenggara Barat), dan Sumba Barat (Nusa Tenggara Timur), bahwa faktor fasilitas tempat bersalin berpengaruh terhadap pilihan tempat bersalin.

Berdasarkan penelitian dapat diketahui bahwa fasilitas kesehatan di tempat bersalin memang menjadi faktor yang penting bagi seorang ibu dalam mengambil keputusan saat memilih tempat bersalin. Hal ini disebabkan ibu mempertimbangkan kelengkapan fasilitas rawat gabung, dukungan fasilitas inisiasi menyusu dini (IMD), kelengkapan fasilitas kegawatan bayi, seperti inkubator, ruang Neonatal Care Unit (NICU), dan yang paling banyak dipilih ibu adalah fasilitas konsultasi tambahan setelah bersalin.

Penelitian menunjukkan bahwa tidak ada hubungan bermakna antara biaya persalinan dengan pilihan tempat bersalin. Hal ini berbeda dengan penelitian Wibowo (1992) yang meneliti tentang faktor-faktor yang mempengaruhi tentang pemanfaatan pelayanan antenatal menemukan bahwa pendapatan keluarga per bulan berpengaruh terhadap pemanfaatan pelayanan kesehatan. Hal ini disebabkan responden penelitian di Kelurahan Kemiri Muka sebagian besar tidak bekerja. Biaya yang dikeluarkan rata-rata bersumber dari suami. Hasil ini juga tidak mendukung hasil penelitian Dasuki, Sutresno, dan Hasibuan, (2000) yang menunjukkan bahwa mahalnya biaya persalinan dan alasan kenyamanan membuat sebagian besar ibu hamil di Kabupaten Purworejo lebih memilih melahirkan di rumah dengan pertolongan dukun.

Berdasarkan penelitian ini dapat disimpulkan bahwa kebijakan yang mendukung proses persalinan tidak menjadi syarat mutlak bagi ibu untuk memilih tempat bersalin. Sebagian besar ibu memilih tempat bersalin yang memiliki sistem rujukan yang baik karena hal tersebut merupakan salah satu hal yang sangat esensial menyangkut keselamatan ibu dan bayi. Sedangkan untuk perizinan melakukan proses pendokumentasian proses persalinan dianggap tidak begitu penting. Hal ini dapat dipengaruhi oleh budaya ibu di mana merekam proses persalinan masih dianggap sebagai hal yang tabu dan ibu belum mengetahui kegunaan dari pendokumentasian proses persalinan tersebut.

Berdasarkan penelitian ini dapat disimpulkan bahwa kebijakan yang mendukung proses persalinan tidak menjadi syarat mutlak bagi ibu untuk memilih tempat bersalin. Sebagian 
besar ibu memilih tempat bersalin yang memiliki sistem rujukan yang baik karena hal tersebut merupakan salah satu hal yang sangat esensial menyangkut keselamatan ibu dan bayi. Sedangkan untuk perizinan melakukan proses pendokumentasian proses persalinan dianggap tidak begitu penting. Hal ini dapat dipengaruhi oleh budaya ibu di mana merekam proses persalinan masih dianggap sebagai hal yang tabu dan ibu belum mengetahui kegunaan dari pendokumentasian proses persalinan tersebut.

\section{KESIMPULAN}

Dari 125 responden didapatkan bahwa 57 orang memilih rumah sakit sebagai pilihan tempat bersalin, baik Rumah Sakit Ibu dan Anak, Rumah Sakit Anak dan Bersalin, Rumah Sakit Bersalin, ataupun Rumah Sakit Umum dan 68 orang yang memilih non rumah sakit, baik klinik bersalin, puskesmas, ataupun bersalin di rumah dengan bidan. Hasil penelitian menunjukan adanya hubungan beberapa faktor yang mempengaruhi Ibu memilih tempat bersalin dengan pemilihan tempat bersalin, yaitu fasilitas kesehatan di tempat bersalin. Faktor-faktor yang tidak berhubungan dengan pemilihan tempat bersalin diantaranya jarak tempat bersalin dengan rumah. Hal ini disebabkan Ibu tidak terlalu mempermasalahkan jarak karena saat ini kendaraan umum sudah banyak tersedia dan mudah didapatkan.

\section{SARAN}

Penelitian selanjutnya diharapkan harus dapat membuktikan kekurangan penelitian saat ini. Oleh karena itu, dalam laporan ini peneliti memberikan saran, yaitu area penelitian dapat diperluas hingga ke seluruh warga Kelurahan Kemiri Muka sehingga hasil penelitian lebih representatif dan dapat digeneralisasi, penelitian ini masih memiliki keterbatasan, maka perlu adanya inovasi baru untuk melakukan penelitian lanjutan dengan memperbaiki rancangan penelitian, menggunakan variabel dan subvariabel yang lebih kuat dimana nantinya lebih valid untuk mengukur apa saja yang mempengaruhi Ibu memilih tempat bersalin. Hal ini diharapkan dapat menjadi masukan bagi perbaikan pelayanan kesehatan.

\section{UCAPAN TERIMA KASIH}

Ucapan terima kasih diberikan kepada sumber dana penelitian yaitu orang tua dan keluarga besar penulis yang mendukung dan membantu dalam penelitian.

\section{Daftar Pustaka}

Alie, Y., Rodiyah. (2013) Pengaruh Batuk Efektif Terhadap Pengeluaran Sputum Pada Pasien Tuberkulosis Paru di Puskesmas Peterongan Kabupaten Jombang. 15. Diakses dari http://stikespemkabjombang.ac.id pada tanggal 3 Mei 2018

Andarmoyo, S. (2012). Kebutuhan Ddasar Manusia Oksigenasi. Yogyakarta: Graha Ilmu

Fitri, M. D. (2017). Pengaruh Akurasi Pemasangan Oksigen Kanula Nasal Terhadap Perubahan Sesak Napas. 9 diakses dari http://idrlibrary.umbjm.ac.id pada tanggal 28 Mei 2018

Muttaqin, A. (2008). Buku Ajar Asuhan Keperawatan Klien dengan Gangguan Sistem Pernapasan. Jakarta: Salemba Medika .

Nasution, S. D. (2015). Malnutrisi dan Anemia Pada Tuberkulosis Paru . 31. Diakses dari http://juke.kedokteran.unila.ac.id pada tanggal 27 Mei 2018.

Nurarif, A. H., \& Kusuma, H. (2015). Aplikasi Asuhan Keperawatan Berdasarkan Diagnosa Medis dan Nanda Nic-Noc. Yogyakarta: Medi Actiion.

Pranowo, C. W. (2009). Efektifitas Batuk Efektif Dalam Pengeluaran Sputum Untuk Penemuan BTA Pada Pasien TB Paru . 7. Diakses dari http://akbidmr.ac.id pada tanggal 26 April 2018 
Rahmaniar, D. S. (2017). Asuhan Keperawatan Pasien Dengan Tuberkulosis Paru . 30. Diakses dari http://pustaka.poltekkes-pdg.ac.id pada tanggal 3 Juni 2018.

Saputra, L. (2014). Buku Ajar Kebutuhan Dasar Manusia. Tangerang Selatan: Binarupa Aksara.

Pontianak. 8. Diakses dari https://media.neliti.com pada tanggal 3 Mei 2018 .

Somantri, I. (2009). Asuhan Keperawatan pada Klien dengan Gangguan Sistem Pernapasan, Edisi 2. Jakarta: Salemba Medika.

Somantri, I. (2008). Asuhan Keperawatan pada Pasien dengan Gangguan Sistemn Pernapasan . Jakarta : Salemba Medika .

Werdhani, R. A. (2013). Patofisiologi, Diagnosis dan Kalsifikasi Tuberkulosis. 6. Diakses dari http://staff.ui.ac.id pada tanggal 29 Mei 2018. 